\title{
MEMORIES OF SYLVIA TOWNSEND WARNER
}

\section{Clive Robbins}

My connection with Sylvia Townsend Warner came through my partnership in music therapy with Paul Nordoff from 1958 to 1977. References to Paul's close friendship with Sylvia are well documented in Letters: Sylvia Townsend Warner (1982); Sylvia Townsend Warner: A Biography (1989) and The Diaries of Sylvia Townsend Warner (1994).

After Paul's death, I became responsible for the effects of the music therapy work he and I had established; I also came to assume responsibility for the musical legacy resulting from his thirty years as a composer that predated his life as a therapist. One small part of this was that I had in my possession an excellent recording of Lost Summer, Paul's setting for Mezzo-Soprano and Orchestra of poems by Sylvia. I worried about whom I should pass this on to. Searching the internet for Sylvia's agent, I came across the Sylvia Townsend Warner Society. Being devoted to Sylvia's writings I joined the Society and became aware of the Dorset County Museum with its Sylvia Townsend Warner-Valentine Ackland Archive. Here was the organization to take care of Lost Summer.

I also learned that if $I$ had any memories of meetings with Sylvia the Society's Journal might be interested in publishing them. 
I met Sylvia on three occasions. The earliest was in the summer of 1960. My first impression on walking into her house at Frome Vauchurch was how well lived-in, active and comfortable it felt. The windows of Sylvia's workroom overlooked the River Frome and its flow dappled the ceiling with reflected sunlight, "What a magical room to write in,' I thought.

Paul and I had driven down from Worcestershire where we were pioneering our creative approach to music therapy with handicapped children. Paul had a long relationship with Sylvia dating back to reading $M r$. Fortune's Maggot (1927) in the mid-thirties, then impetuously writing an opera based on the story. Correspondence with Sylvia followed in which she graciously granted him permission to do what he had already done and suggested that his librettist approach her American publisher for permission, with a view to possible performance.

She first experienced Paul's music in 1939 in New York City when he sent her the score of Mr. Fortune. In response, she wrote him a letter of such unreserved and discerning appreciation that it must have lifted him beyond the relief of gaining acceptance into the joy of having his devotion to the story and his gift for composition so wholeheartedly acknowledged. They met later that year in Connecticut. Thereafter, they declared their affection for each other, and Paul often quoted from Sylvia's letter that followed their meeting:

It is so gratifying of you to say in your letter that you like me. Things of that kind, which can be very important, people usually omit to mention. Personally, I have no use for unexpressed affection, and so I will most readily reply that I like you a great deal, and look on my meeting with you as one of the best things $I$ have found in this country. 
Sylvia continued to be a strong presence in Paul's life. Living and working in England in 1960, it was natural for him to want to share his new creative life in music therapy with her. He wanted to introduce me to her and also felt I should 'experience' Sylvia. Paul and I had begun to develop our work together the previous September and it was obvious from the positive effects it was having on the children with whom we were working that we were on to something substantial. Into this new venture-as original and creative as anything he had ever done-he was bringing his thirty years of experience as a canny, versatile composer, brilliant pianist, and professor of music. He was fifty when he made the transition, eighteen years my senior. In return I was bringing to the teamwork all I had learned as a special education teacher and house parent in my six years at Sunfield Children's Home in Worcestershire, together with my love of music, especially now his music, plus my interest in taking care of practical matters. We made a natural team and worked easily together.

At that time, I had never read Sylvia, and there was nothing in my upbringing or education that could have prepared me for meeting her. She invited me to take a walk around the garden; I was daunted and tongue-tied in her presence, yet totally fascinated. She put on a lively and delicious lunch-her menus were renowned for their originality. Another guest joined us - I believe it was Janet Machen - and in a party spirit we became mildly disrespectful to figures of public authority. This led Sylvia into proposing a toast to "Her Hippophagic Majesty, the Queen!"

Later, at the piano, Paul and I presented our work. We played and demonstrated songs and games, stories and musical activities that had been created for children with the practical intention of helping them overcome the effects of conditions such as severe learning disability, autism, and physical handicaps. As most of the work we presented was for groups of children there was a firm emphasis on rhythmic form to hold the groups together. I wondered if Sylvia fully appreciated the extent of the 
children's disabilities and the processes of development we were working to engage. This was for her an entirely new field of human need and musical endeavour, and her response, though closely attentive, was somewhat muted. I think too, that the Paul she saw enthusiastically playing and singing his music for the enrichment of children she had earlier, in the terminology of the time, categorized as 'defectives,' was not the Paul with whom she had collaborated on Mr. Fortune and The Sea Change, and who had expressed the pathos of Lost Summer so exquisitely.

Paul was an extraordinary composer. When Sylvia wrote of his settings of her librettos her letters were eloquent with her recognition of his genius. He owned a natural sublimity of invention that was faultiess. And yet his music for therapy was no less inspired, and finely, knowingly, written or improvised, although it was not to be fully understood in exclusively aesthetic values.

After this visit we were not to meet Sylvia again for ten years, but a fond connection was sustained in two ways. Her letters to Paul, arriving in Pennsylvania and, for a time, Kansas, were always a cause for celebration and were eagerly read aloud. News updates were sent in return. For relaxation we also took turns in reading aloud her short stories and novels.

We had been fortunate in landing a series of important music therapy research and demonstration projects. These brought Paul the responsibility of improvising for, and with, more than twenty children individually each week. Each child's course of therapy became a creative journey into a particular personalized body of music. How it developed was determined in each case by the child's needs, difficulties and mode of musical response. Recording and analyzing each session was mandatory for musical consistency and accurate documentation. Maintaining such concurrent courses of therapy over many months became essentially a many layered, drawnout compositional process that fully demanded Paul's musical commitment. Additionally, we were working 
with several groups which often called for the writing of new works.

For these reasons we were drawn to living almost monastically with no television, no radio, and rarely a newspaper. Instead, we read aloud to each other in the evenings. Sylvia's writings were naturally a top choice. As most of her books were out of print, we made a hobby of raiding second-hand book stores and garage sales (this was long before Amazon.com and online used book dealers). There was always great excitement in discovering 'a new Sylvia!' Over the next fourteen years we were to read pretty well everything she had written.

Paul had originally planned a visit to Sylvia in 1969, but Valentine's terminal illness forced a postponement until the spring of 1970. Valentine's death had left Sylvia bereft since November and we arrived to find her in a vulnerable state, her moods restless and volatile. Valentine's presence coursed through the house as Sylvia spun out a succession of memories that swung urgently between rapturous joy and abject pain. Much of what she poured out to us in those days has since appeared in print, but perhaps not all.

I remember a calm evening sitting by the fire in the stillness of her comfortable sitting room; I had been impressed by the extraordinary Craske embroidery seascape above the mantelpiece and felt that the character of the room fitted Sylvia as personally as the clothes she wore. We talked about Peter Pears and Benjamin Britten. Sylvia had introduced Paul to Ben in 1958 and they had become friends. Two sleek, elegant Siamese cats lay on the rug, lazing in the heat of the fire and looking supremely content. At sometime in the evening a large tabby came in, the kind of unremarkable cat one might see at any farmhouse. There was a subtle repositioning as the Siamese made room for the tabby. "They think he's so exotic," said Sylvia, "but he's as ordinary as a tea cosy." As the cats settled in and slept with well-accustomed ease they radiated a bond of attachment that embraced Sylvia with palpable comfort. It was evident that they needed her presence as much as she needed theirs. Whenever I read 
her late diary entries or the letters from this period in which she several times mentions the three cats, it is this image that comes to mind: Sylvia contemplative in her armchair with her three close companions in that peaceful firelit room.

The following day, she and I were in the kitchen washing up after lunch, Sylvia at the sink, I was drying. As she passed me a silver table knife she told me that Valentine had given her a complete set of silverware. Sadly, she said she had dropped a knife that had fallen through a gap between the floorboards. I knew she was aware that nothing would please me more than a chance to be of practical help, so I offered to rescue the knife. We rummaged around in the lumber room adjoining the kitchen until we found something that would serve as a crowbar. The old floorboard came up easily and there, shining in the dark, was the lost knife. I remember how she stood by the kitchen window in the soft light reflecting from the river, holding the treasured knife and smiling with tender happiness as she quoted, 'Of them which thou gavest me have I lost none'. (John 18:9) It is one of my most cherished memories.

In $2008 \mathrm{I}$ visited the Sylvia Townsend Warner Valentine Ackland Archive at the Dorset County Museum in Dorchester. I was there to pick up photocopies of the score of Mr. Fortune for the Paul Nordoff Archive we were assembling in New York. Unexpectedly, a file of correspondence was opened and a postcard taken out and handed to me. I was stunned to find myself holding a postcard I had written to Sylvia following the 1970 visit. To realize that she had kept it was more deeply stirring than I can say. I am moved to include it here a) because she kept it, b) because it captures my admiration and fondness for her, that somehow I had had the courage to put into words, and c) because I feel emboldened to follow her predicate that feelings of affection should not be left unexpressed.

On the front of the postcard was a picture of a medieval statuette of four angels. On the reverse I had written: 
This delight comes from us both. Oh Sylvia! What stories. What glory and pathos, what beautiful characters, and what dolts. Your stories are initiations into the world. And that wonderful wicked wit. And as I read last night we left this house and I was sitting in your room, warmed by your fire, the cats at my feet. (Your house, home - your smithy where your anvil rings so busily, happily for all the desolation of the smith.) And how divinely you make them. They come sailing out of the seas of creation like well-rigged ships. Bless you, greatest Sylvia, Clive.

In 1971, Gollancz published Paul's and my first book in England, Therapy in Music for Handicapped Children. We had sent Sylvia a prepublication copy, happy to give her the chance to learn more of the scope and variety of what we were doing, and how we were thinking and writing about it. She wrote an enthusiastic blurb for Gollancz. It has long been lost, but I remember it began, 'This is an adventure story, its theme the release of prisoners. ...' She also drew attention to the title as it emphasized that therapy was inherent in music itself, and not merely in its application. Ben Britten had contributed a preface.

The third occasion of meeting Sylvia was in the spring of the following year when Paul and I were in a position to invite her to visit us in Denmark. We were working on our third and major book, Creative Music Therapy: Individualized Treatment for the Handicapped Child. We had been writing the book piecemeal over the last five years amid the teaching, lecturing, and demonstrating that had us travelling in Europe and Scandinavia. Through the link of a fortuitous connection we were awarded a writer's grant by the Axel Springer Verlag in Berlin that gave us the year of freedom and security we needed to pull the book together. As Paul had always felt comfortable in Denmark - he found its standard of living, 
peacefulness, and climate congenial-we rented a small house in quiet farmland just north of Copenhagen.

We worked through the fall of 1971 and, once the worst of winter was over, set about inviting Sylvia to visit us. She agreed she needed to get away, but because she refused to fly was dependent on British Rail to get to and from the ferry at Harwich; this at a time when Britain was wracked with industrial conflict and threats of strikes. There were days of delay and indecision. However, the situation improved and in March she took a chance on the travel. It was a journey she completely enjoyed and in perfect early spring weather we welcomed her at the main station in Copenhagen.

After an obligatory visit to Tivoli, just across the street from the station, we drove her out to the house on the outskirts of the village of Kirke Værløse. She was delighted with it, particularly as her improvised bedroom looked out on gently rolling farmland and a field of rising, passionately singing larks. She was such an alert, sprightly presence in the house, her voice was bright with melody, and her sense of humour always ready to break out. One of the first things she did on settling in was to proclaim "I've thrown my bonnet over the haystack!" and eagerly share the news that she had begun writing stories from the Kingdom of Elfin.

Paul and I had invited Sylvia for two reasons: we knew that getting away from Frome Vauchurch for a complete change would be good for her, and we were inviting her approval and advice on what we were writing. In a letter to Marchette and Joy Chute, written after her return and describing the pleasures of her visit, she wrote:

They are writing (did I tell you?) a book about their methods of therapy by music; and were at the stage of knots in it; and in the mornings we disentangled the knots $\&$ in the afternoons went out to play.

(Warner, 1982, p.256) 
And play we did! We walked in the Dyrehavn, took her to the Louisiana Museum of Modern Art, crossed the Ǿresund into Sweden, and from a distance viewed Kroningborg (Hamlet's) Castle. In the same letter she gives an account of her visit to the church in Kirke Værløse but omits to report on her visit to the graveyard. As we browsed around the headstones she remarked in a rather arch voice, "Paul, I had no idea so many Danes were named Fred!" ('Fred' being Danish for peace and tranquillity.)

At home we cooked, ate festively, and had music. Paul had taken to playing Mozart more slowly than was customary. He was deeply affected by how the creative genius was thus re-disclosed, and he shared his new experiences. He also played and sang for her his settings of poems by Walter de la Mare. It was a rare experience to hear two such wise practitioners discuss, as old friends, the merits of the various compositions.

But beyond the playtime, it was the work on the book that was for me deeply and unforgettably powerful. In writing about music therapy, especially about a practice that was richly, livingly musical, Paul and I had suffered agonies of frustration over the inability of words to convey the essence of the interactive musical communing between therapist and child which was the modus operandi of Creative Music Therapy. In writing about music one could describe, qualify, categorize, one could write around music, but only music could communicate music and say what we knew we had to say. Accordingly, we proposed to the publishers that recordings taken from improvisational music therapy sessions be included in the book.

They had the vision to agree, and undertook to produce what would be the first professional music therapy text to contain selected excerpts taken from clinical practice. (I am using the word 'clinical' with some concern lest it be taken to imply an approach that was cold and sterile. Far from it! In this context 'clinical' signifies the quality of intent with which live vocal and/or piano improvisation is interresponsively focused on a child's emergent 
response process, however this may be expressed through singing, playing instruments, or movement.)

The recording technology at the time allowed us to include up to one hour of illustrative excerpts in the book. What this meant for Sylvia's work with us was that for any particular child, we would be listening to selected clinical excerpts in the context of what we had written in documenting the events and processes of therapy. Equally, we would be reviewing the text in the context of the musical realities made accessible through the recordings. Each recorded excerpt from a course of therapy was accompanied in the text by an annotated paragraph detailing its content; this would serve as a guide to listening and study. A series of illustrative excerpts would then appear chronologically in the text as the story of the child in therapy unfolded. The result would be a book as much to be listened to as read.

It was demanding work, bringing together two interrelated narratives to communicate what was happening in therapy. In a sense, a marriage between text and music was nothing new for Sylvia: earlier in her career as a musicologist she had worked for more than ten years on editing the immense collection of English sacred music that would be published by Oxford University Press. However, the differences between that project and the one in which we were inviting her consultation were that this was music to be heard; it originated in the spontaneity of improvisation; and at the core of the work we were addressing musically inspired transformational events in the individual biographies of children.

Although Paul and I worked as co-authors, much of the responsibility of planning and writing the book had passed to me, so it was my role to lead Sylvia into the heart of the work. We all three had a copy of the manuscript; I operated the tape player and presented the story of the course of therapy with each child. As Sylvia listened and considered, read and discussed, I was in awe of the intensity of her powers of concentration. Sitting close beside her one felt her committed attention physically, as tangible living energy. As we moved back 
and forth between music and text, I have a memory of us bent over the work together and Sylvia saying in all seriousness, "This is a big surprise for me." She understood immediately when Paul described how he saw the effects of a particular technique or the choice of a modal scale or musical idiom, or spoke of the "Music Child,' a child's inborn musicality; then they talked as musicians. She fully concurred with Paul's view that music based on a particular tonality could become a womb in which a child could find nurturance.

I remember how impressed she was by the spirited independence of an eleven-year-old girl - learning disabled, blind and with cerebral palsy - vocally improvising antiphonally, joyfully with Paul, and through playing a drum and cymbal bringing coordination to the movements of her arms. In the suggestions Sylvia made for the text, she accorded the girl immeasurable dignity. She was completely with us as we moved on from one child to the next, confirming the rightness of our plan for the book, and strongly affirming Paul's approach throughout.

One of the knots we had to tackle was the question of writing style. The book was to be published as a professional text, yet we did not want a stilted academic style. She approved the broad humanly descriptive approach we had taken. All in all, no radical changes were necessary, but she put in countless refinements, always with a naturally telling phrase that captured an important step in a child's progress. Wherever she made an addition or suggested a change in the turn of a phrase it was deft, expert, to the point, and added to our technique in the writing we were to do later. Her amendments fitted seamlessly into our style, but on rereading what we did I still recognize her sure touch; her contributions are still there in the second edition (2007).

Those four mornings spent working on Creative Music Therapy were the culmination of my relationship with Sylvia. It was a rare and unique privilege to work so closely with her and to receive from the greatness of her genius such wise, practical guidance, and all while being 
graced by her friendship. How she guided us was to have the further legacy of indirectly influencing the standard of literacy aspired to by later practitioners of the NordoffRobbins approach to music therapy as they tackled the challenge of representing the phenomena of creative music therapy in words and recordings.

I would like to close these memories with Sylvia having the last word on the dichotomy between artistic creation and scientific analysis. The professional enthusiasm with which our work was received in the Philadelphia area had its origins in a course of psychoanalysis Paul had undergone there in his early thirties. The outcome was successful, and he and his analyst formed a fond, lasting relationship. The analyst had gained a high opinion of Paul as a person, and profound admiration for him as a composer-pianist. When, two decades later, we were invited to demonstrate our work in the Philadelphia area, this same analyst, now a professor of psychiatry and an eminent authority on child psychotherapy, became a guiding mentor, and was a benign influence on how our initiatives were professionally accepted and supported. I told Sylvia that as we were setting up therapy programs, this dedicated colleague adopted a typically scientific stance and declared "Now we can harness Pegasus to the plough!" Sylvia laughed and then put the matter in its true perspective: "No, that's wrong," she observed. "It's the plough that gets harnessed to Pegasus!"

$$
* * *
$$

I was not to meet Sylvia again, although Paul did. Beginning in 1975 he and I ceased our close teamwork. We continued teaching and developing our work, but separately. He became ill, recovered but relapsed. He died in January 1977. Sylvia was asked to write his obituary for The Times. She died the following year. The work to which Paul and I gave birth gained social, financial, and academic support and thrived. Since 1974, the Londonbased Nordoff-Robbins Music Therapy Charity has trained over 250 music therapists up to the $\mathrm{PhD}$ level. 
Currently it has a staff of 50 therapists, operates 70 regional services in the UK and provides some thirty-five thousand sessions of music therapy annually. The work has also spread globally and is taught and practiced in many European and Asian languages. This ongoing expansion owes much to the book that Sylvia helped to bring to completion.

\section{WORKS CITED}

HARMAN, C. (1989) Sylvia Townsend Warner. A Biography. London, Chatto \& Windus.

NORDOFF, P. and ROBBINS, C. (1971) Therapy in Music for Handicapped Children. London, Gollancz. Revised edition (2006) Gilsum, N.H., Barcelona Pub.

. (1977) Creative Music Therapy: Individualized Treatment for the Handicapped Child. New York, John Day. Expanded and revised edition (2007) published as Creative Music Therapy: a Guide to Fostering Clinical Musicianship. Gilsum, N.H., Barcelona Pub.

WARNER, S. T. (1927) Mr Fortune's Maggot. London, Chatto \& Windus.

Chatto \& Windus.

. (1982) Letters. Ed. William Maxwell. London, . (1994) Diaries. Ed. Claire Harman. London, Chatto \& Windus. 


\section{Copyrighted image removed}

Sylvia Townsend Warner with Paul Nordoff in the churchyard at Kirke Værløse during her visit to Denmark in March 1972.

(C) Clive Robbins 